\title{
STIMULASI SENI DALAM MERANGSANG LIMA ASPEK PERKEMBANGAN ANAK USIA DINI MELALUI PERMAINAN TRADISIONAL GEDRIK
}

\author{
Tantra Sakre \\ Prodi Pendidikan Seni Rupa, Universitas PGRI Adi Buana Surabaya \\ tantrasakre@unipasby.ac.id
}

\begin{abstract}
Abstrak
Pendidikan anak usia dini yang sering kali disebut masa keemasan atau golden age (usia emas) pada masa pertumbuhan dan perkembangan anak. Pada dasarnya di usia emas inilah stimulasi sesuai kelompok usia diperlukan untuk melakukan pengembangan secara menyeluruh dari berbagai macam aspek, termasuk salah satunya adalah aspek seni. Salah satu kegiatan yang dapat merangsang perkembangan anak usia dini adalah kegiatan bermain. Tujuan bermain pada anak maupun orang dewasa bukan hanya untuk kesenangan individu belaka. Melalui sebuah permainan seorang anak dapat belajar banyak hal, karena dengan bermain anak-anak merasa senang dan mampu berkonsentrasi lebih lama sehingga kemampuan mengingat mereka menjadi lebih baik (Delima et al., 2015). Alat permainan edukatif yang akan dipilih adalah permainan tradisional Gedrik. Tujuan dari penulisan ini adalah untuk menganalisis permainan tradisional Gedrik yang menjadi media stimulasi seni dalam merangsang lima aspek perkembangan anak usia dini.
\end{abstract}

Kata Kunci: Stimulasi Seni, Permainan Tradisional, Gedrik

\section{PENDAHULUAN}

Pendidikan anak usia dini merupakan basis untuk melanjutkan pada jenjang pendidikan selanjutnya. Pendidikan anak usia dini yang sering kali disebut masa keemasan atau golden age (usia emas), pendidikan anak usia dini dilaksanakan sejak usia 0-8 tahun. Dalam masa usia emas anak usia dini terdapat pembagian ruang lingkup yang meliputi, bayi (0-1 tahun), batita (2-3 tahun), kelompok bermain (3-6 tahun) dan usia awal sekolah (6-8 tahun). Teori Piagetian Conception of Development menjelaskan mengenai pembagian tahapan perkembangan kognitif (cognitive theory) dalam empat tahap yaitu tahap sensorimotor (0-2 tahun), tahap praoperasional (2-6 tahun), tahap operasional konkret (6-11 tahun), dan tahap operasional formal (11-16 tahun). "the structuralist aspect concerns the sequence of four qualitatively different stages : sensorimotor stage (0-1,5 years), pre-operational stage (2-6 years), concrete-operational stage (6-11 years), and formal-operational stage (beginning 11 or 12 years to around 16 years). " (Inagaki, 1992). 
Pada dasarnya di usia emas inilah stimulasi sesuai kelompok usia diperlukan untuk melakukan pengembangan secara menyeluruh dari berbagai macam aspek, termasuk salah satunya adalah aspek seni. Pengembangan anak secara menyeluruh dari berbagai aspek ini bisa juga disebut dengan istilah global learning. Global learning meliputi joyful learning, attractive learning, dan active learning. (Rolina, 2010). Pengembangan secara menyeluruh untuk pada anak usia dini dimaksudkan dengan tujuan untuk mengembangkan seluruh aspek yang ada pada diri anak, sehingga kemampuan perkembangan pada anak tidak hanya menekankan pada perkembangan otak kiri saja.

Terdapat kerangka berpikir yang telah berkembang di masyarakat Indonesia tentang proses belajar mengajar, yang mana dalam proses tersebut identik dengan kegiatan tulis menulis. Paradigma tersebut secara tidak langsung telah mematikan kreativitas anak dan menghambat tumbuh kembang anak pada tahaptahap selanjutnya. Anak-anak usia dini pada dasarnya memiliki keterbatasan pada kemampuan verbalnya, menyukai percobaan dan aktivitasaktivitas yang secara aktif ikut menyertakan mereka, mereka juga menyukai permainan yang mudah dipahami dan menyesuaikan dengan kemampuan anak.

Salah satu kegiatan yang dapat merangsang perkembangan anak usia dini adalah kegiatan bermain. Tujuan bermain pada anak maupun orang dewasa bukan hanya untuk kesenangan individu belaka. Melainkan suatu kebutuhan yang harus dipenuhi, terutama bagi anakanak. Bermain merupakan hal yang sangat penting bagi anak-anak, karena bermain merupakan salah satu aktivitas yang dapat membantu anak ke arah perkembangan dan perubahan positif baik dari segi mental, seni, dan jasmani. Melalui sebuah permainan seorang anak dapat belajar banyak hal, karena dengan bermain anak-anak merasa senang dan mampu berkonsentrasi lebih lama sehingga kemampuan mengingat mereka menjadi lebih baik (Delima et al., 2015). Alat permainan edukatif yang akan dipilih adalah permainan tradisional Gedrik, dengan nama lain Engklek, konclong, Angkle, dan lain-lain sesuai dengan bahasa daerah masing-masing. Permainan gedrik adalah permainan lompat-lompatan pada bidang datar yang digambar pola kotak-kotak kemudian lompat dari satu kotak ke kotak berikutnya.

Berdasarkan dari uraian latar belakang di atas, maka dapat dirumuskan rumusan masalah sebagai berikut : Apakah permainan tradisional Gedrik dapat menjadi 
media stimulasi seni dalam merangsang lima aspek perkembangan anak usia dini?

Tujuan dari penulisan ini adalah untuk menganalisis permainan tradisional Gedrik yang menjadi media stimulasi seni dalam merangsang lima aspek perkembangan anak usia dini.

\section{METODE PENELITIAN}

Pendekatan yang digunakan dalam penelitian ini adalah pendekatan penelitian kualitatif. Metode penelitian kualitatif merupakan serangkaian prosedur yang menghasilkan data deskriptif berupa kata atau kalimat yang tertulis atau lisan dari orang-orang dan perilaku yang dapat diamati. Menurut Lexy J.Moleong (2007) dalam penelitian kualitatif, peneliti atau dengan bantuan orang lain merupakan alat pengumpul data.

Teknik pengumpulan atau koleksi data dari penelitian ini adalah observasi, wawancara, dan kajian literatur. Wawancara dilaksanakan kepada orang tua dan anak Pendidikan Usia Dini sebagai objek penelitian. Penelitian ini menggunakan sintesis dari kajian-kajian literatur transmedia yang diambil baik cetak maupun digital dari berbagai sumber, sebagai data sekunder.

\section{HASIL DAN PEMBAHASAN}

Stimulasi seni merupakan aktivitas untuk mendorong kemampuan dasar anak menggunakan media seni untuk mengoptimalkan secara menyeluruh pertumbuhan dan perkembangan anak. Hal tersebut juga merupakan tujuan dari pendidikan anak usia dini. Sebagaimana tercantum dalam Undang-Undang Nomor 20 Tahun 2003 tentang Sistem Pendidikan Nasional, bahwa "Tujuan Pendidikan Anak Usia Dini adalah untuk membantu dalam mengembangkan potensi-potensi yang ada pada diri anak". Tujuan pendidikan kanak-kanak adalah untuk memfasilitasi pertumbuhan dan perkembangan anak secara optimal dan menyeluruh, sesuai dengan norma-norma dan nilai kehidupan yang dianut (Rosmiati, 2014). Melalui pendidikan ini diharapkan perkembangan lima aspek pada anak yaitu aspek kognitif, bahasa, sosial, emosional dan aspek motorik pada anak dapat berkembang dengan baik. Berkaitan dengan hal tersebut, penerapan model pembelajaran bersifat klasikal, yang diisi dengan kegiatan anak yang diberi majalah atau buku bacaan kemudian dilanjutkan dengan kegiatan mengerjakan tugas. Model pembelajaran klasikal juga cukup menjenuhkan apabila ditinjau dari segi psikologi anak, menyukai kegiatan yang melibatkan mereka secara aktif sedangkan metode yang lebih sering digunakan adalah metode ceramah sehingga anak tidak memiliki cukup ruang untuk mengeksplorasi diri. 
Terlebih pada masa-masa anak usia dini, anak memiliki keterbatasan pada kemampuan verbal, metode ceramah dirasa akan menghambat perkembangan bahasa, sosial, emosional dan motorik pada anak. Model pembelajaran klasikal ini sangat kurang dalam pengembangan dan penyaluran minat anak, sehingga anak tidak diberikan kebebasan berekplorasi, berkreatifitas maupun menemukan jawabannya sendiri atas setiap pertanyaan mereka (Syamsuardi \& Hajerah, 2018).

Sekarang ini tidak sedikit tenaga pendidik yang telah menerapkan belajar sambil bermain untuk menciptakan suasana belajar yang menyenangkan. Tentu saja permainan yang dimaksudkan tidak hanya sekedar berisi muatan materi yang ingin disampaikan akan tetapi perlu dikemas dengan tetap memperhatikan psikologi anak, sehingga dapat mengembangkan aktivitas mental dan sosial anak. Aktivitas belajar sambil bermain juga diyakini mampu menumbuhkan regulasi diri pada anak, hal tersebut dikarenakan dalam setiap permainan anak-anak usia 0-7 tahun terdapat suatu peraturan. Hal tersebut merujuk pada konsep bermain menurut Vygotsky yang mendefinisikan hubungan antara bermain dan perkembangan mental anak dengan sangat spesifik. Vygotsky menjelaskan bahwa situasi yang imajinatif (dalam bermain) selalu terkandung peraturan, akan tetapi Vygotsky hanya membatasi ruang lingkup permainan pada permainan make-believe play (MBP) atau permainan peran sehingga tidak merujuk pada aktivitas "pergerakan" dan eksplorasi diri pada anak. Hal tersebut sebagaimana dikemukakan oleh Vygotsky sebagai berikut.

"...we have received proof comparatively recently that so-called pure games with rules (played by schoolchildren and late preschoolers) are essentially games with imaginary situations; for just as the imaginary situation has to contain rules of behavior, so every game with rules contains an imaginary situation." (Vygotsky, 1967).

Beberapa jenis permainan dapat menjadi media alternatif untuk eksplorasi diri pada anak dengan mempertimbangkan karakteristik dan aspek-aspek perkembangan anak. Kita dapat memilih permainan dengan berbasis budaya tradisional, misalnya Gedrik.

Gedrik adalah permainan yang dilakukan dengan mengangkat satu kaki kemudian melompati antar petak hingga selesai, terkadang terdapat petak-petak tertentu yang harus dipijak dengan dua kaki. Permainan ini juga membutuhkan batu pipih, pecahan keramik atau genting yang sudah ditumpulkan yang disebut gaco untuk dilemparkan ke dalam petak. 
Permainan ini melibatkan banyak anak yang permainan ini bersifat kooperatif sehingga permainan ini dapat dijadikan sebagai model pembelajaran. Hasil pembelajaran menunjukan bahwa permainan tradisional Jawa, anak dimungkinkan lebih banyak bermain secara kelompok dan sering berinteraksi dengan teman sebaya serta guru yang memberikan arahan sehingga anak lebih cepat akrab dan dapat bekerja sama dengan teman sebayanya (Nourovita, 2013). Berikut ini merupakan salah satu desain arena atau petak yang digunakan dalam permainan gedrik :

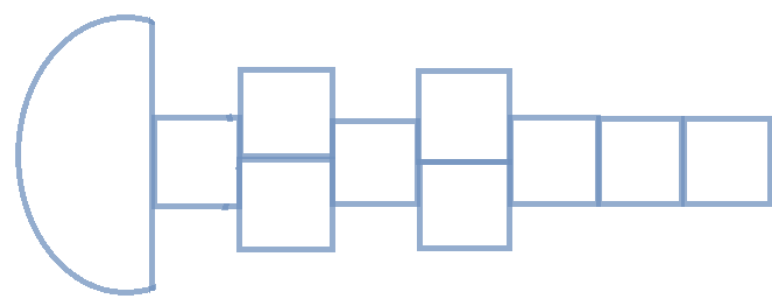

Gambar 2.1 Petak atau arena permainan Gedrik berbentuk gunungan (sumber : penulis)

Stimulasi seni yang dapat diberikan melalui permainan Gedrik adalah melatih kreativitas anak, kreativitas yang ditujukan untuk anak usia dini adalah kreativitas yang tidak hanya ditampilkan dalam bentuk permainan peran saja akan tetapi menyangkut pada permainan dengan gerakan yang menunjang segala aspek. Sementara yang dimaksudkan dengan kreativitas untuk anak usia dini, taman kanak-kanak (TK) ditampilkan dalam berbagai bentuk, baik dalam bentuk gambar yang dia sukai, bercerita, bermain peran ataupun menampilkan berbagai gerakan yang berkaitan dengan aktivitas motoriknya (Astuti, 2013). Pada dasarnya permainan tradisional dibuat sendiri oleh pemainnya secara langsung, mereka dapat memanfaatkan benda-benda yang ada di sekitar, bebas berkreasi pada petak permainan Gedrik sehingga memberikan peluang kepada anak untuk menyibukan dirinya secara kreatif, mereka juga dapat mengekspresikan pikirannya tanpa batas. Hal tersebut akan berdampak pada peningkatan kualitas diri anak serta memberikan dampak kepuasan tersendiri bagi anak yang akan mempengaruhi perkembangan sosial dan emosional anak. Belajar melalui rangsangan seni dapat berpengaruh dalam perkembangan aspek kognitif, bahasa, sosial, emosional dan aspek motorik pada anak. Sehingga kecerdasan seni dapat membantu pola pikir dan mempengaruhi perkembangan lain melebihi kecerdasan lainnya.

\section{SIMPULAN}

Masa pendidikan anak usia dini yang dimulai sejak usia 0-8 tahun merupakan 'usia emas' terlebih pada usia empat tahun pertama yang merupakan masa 
perkembangan anak yang paling kritis. Oleh karena itu stimulasi yang dapat diberikan untuk merangsang seluruh aspek perkembangan anak merupakan stimulasi seni. Adapun media yang dapat digunakan adalah permainanpermainan tradisional, contoh yang dapat dipakai adalah permainan Gedrik dalam bahasa Jawa atau secara umum lebih dikenal dengan sebutan permainan engklek. Selain menjadi media stimulasi seni pada anak, permainan tradisional Gedrik ini dimaksudkan sebagai bentuk pelestarian permainan tradisional ditengah pesatnya perkembangan permainan modern sekarang ini.

Terkait dengan hal teersebut sangat dibutuhkan kepedulian dari tenaga pendidik untuk memahami psikologi anak usia dini, memberi dorongan dan dukungan yang positif guna mengembangkan seluruh aspek perkembangan pada anak (perkembangan aspek kognitif, bahasa, sosial, emosional dan aspek motorik) sehingga tidak akan menghambat tumbuh kembang serta potensi yang dimiliki anak.

\section{DAFTAR PUSTAKA}

Astuti, F. (2013). Menggali dan Mengembangkan Potensi Kreativitas Seni pada Anak Usia Dini. Komposisi: Jurnal Pendidikan Bahasa, Sastra, Dan Seni, 14(1).
Delima, R., Arianti, N. K., \& Pramudyawardani, B. (2015). Identifikasi kebutuhan pengguna untuk aplikasi permainan edukasi bagi anak usia 4 sampai 6 tahun. Jurnal Teknik Informatika Dan Sistem Informasi, 1(1).

Inagaki, K. (1992). Piagetian and postpiagetian conceptions of development and their implications for Science Education in early childhood. Early Childhood Research Quarterly, 7(1), 115-133.

Nourovita, A. R. (2013). Efektivitas Permainan Tradisional Jawa dalam Meningkatkan Penyesuaian Sosial pada Anak Usia 4-5 tahun di Kecamatan Suruh. BELIA: Early Childhood Education Papers, 2(1).

Rolina, N. (2010). Memahami Psikologi Perkembangan Anak Bagi Pengembangan Aspek Seni Anak Usia Dini. Retrived from Https://Www. Staff. Uny. Ac. Id/Sites/Default/Files/Tmp/Artike l-Unk-P4tksb. Pdf.

Rosmiati, A. (2014). Teknik stimulasi dalam pendidikan karakter anak usia dini melalui lirik lagu dolanan. Resital: Jurnal Seni Pertunjukan (Journal of Performing Arts), 15(1), 71-82. Syamsuardi, S., \& Hajerah, H. (2018). Penggunaan Model Pembelajaran 
pada Taman Kanak-Kanak Kota

Makassar. Jurnal CARE (Children

Advisory Research and

Education), 5(2), 1-7.

Vygotsky, L. S. (1967). Play and its role in the mental development of the child. Soviet Psychology, 5(3), 618. 